\title{
Accuracy of Diagnostic Methods for Detection of Head and Neck Primary Origin in Metastatic Neck Mass
}

\author{
Hong Dae Kim, Hyung Jun Yoon, Keon Ho Kim, \\ Chang Myeon Song, Yong Bae Ji, and Kyung Tae \\ Department of Otorhinolaryngology-Head and Neck Surgery, Hanyang University College of Medicine, Seoul, Korea
}

\author{
전이성 경부 종물에서 두경부 원발 부위 진단방법의 정확도 \\ 김홍대 · 윤형준 · 김건호 · 송창면 · 지용배 · 태 경 \\ 한양대학교 의과대학 이비인후-두경부외과학교실
}

\author{
Received July 8, 2017 \\ Revised September 2, 2017 \\ Accepted September 25, 2017 \\ Address for correspondence \\ Kyung Tae, MD, PhD \\ Department of Otorhinolaryngology- \\ Head and Neck Surgery, \\ Hanyang University \\ College of Medicine, \\ 222 Wangsimni-ro, Seongdong-gu, \\ Seoul 04763, Korea \\ Tel $+82-2-2290-8588$ \\ Fax +82-2-2293-3335
}

E-mail kytae@hanyang.ac.kr
Background and Objectives It is important to localize the primary site when cervical lymph node metastasis is detected. The purpose of this study was to evaluate the accuracy of diagnostic methods to detect the head and neck primary site in patients with metastatic neck mass.

Subjects and Method Sixty-six patients who had presented with neck mass and were confirmed to have metastatic carcinoma by fine needle aspiration cytology from January 1998 to June 2016 were enrolled. We analyzed the accuracy of diagnostic modalities that inluded physical and endoscopic examination, CT, MRI, PET/CT, and guided biopsy.

Results The mean age of patients was $58.7 \pm 12.6$ years with the male to female ratio of $55: 11$. The metastatic lymph nodes were most common at level II $(60 / 66,90.9 \%)$ followed by levels III, IV, I and V. The most common primary site was tonsil (45.5\%), followed by the nasopharynx, base of tongue and hypopharynx, and eight patients $(12.1 \%)$ were diagnosed as metastatic carcinoma of unknown origin. The primary sites were detected by: physical and endoscopic examination in 36/66 (54.5\%), CT in 41/66 (62.1\%), MRI in 39/52 (75\%) and PET/ CT in $46 / 63$ (73.1\%). The primary sites were additionally detected using PET/CT for nine cases of the 20 cases, where primary sites were not found using physical and endoscopic examination, CT or MRI. Guided biopsy was done in 11 cases, where primary sites were not detected by all of the methods; hence, primary sites for 3 cases were additionally revealed.

Conclusion PET/CT is a useful method when physical examination, CT and MRI cannot reveal the primary site of metastatic neck mass. Guided biopsy can be performed when primary site is not founded by any of the physical and imaging examinations.

Korean J Otorhinolaryngol-Head Neck Surg 2017;60(12):664-9

Key Words Diagnosis - Guided biopsy - Head and neck cancer · Metastatic neck mass · Unknown primary tumor.

\section{서 론 \\ 경부 종물을 주소로 내원하는 환자의 원인은 매우 다양하 \\ This is an Open Access article distributed under the terms of the Creative Commons Attribution Non-Commercial License (http://creativecommons.org/licenses/by-nc/4.0) which permits unrestricted non-commercial use, distribution, and reproduction in any medium, provided the original work is properly cited.}

며 크게 염증성, 선천성, 종양성 종물로 나뉜다. ${ }^{1,2}$ 그중 악성
종양은 40 세 이상에서 많고, 남성이 여성보다 흔하다. 크기가
점차 커지거나 $1 \mathrm{~cm}$ 이상인 경우에는 악성일 가능성이 많고
뚜렷한 증상 없이 오랫동안 크기의 변화가 없을 때는 양성인
경우가 많다. ${ }^{1,2)}$ 악성 종물은 대부분 무통성이나, 염증성 종물
은 압통을 동반한 경우가 많다. 또한 단단하고 주위와 유착이 
있는 경우 악성을 의심할 수 있으며 양성은 대개 부드럽고 유 동성이 있다. 악성종양의 림프절 전이는 측경부에 호발하며, 특히 level II(30 50\%)가 가장 흔하고 다음 차례로 level I, III가 10 20\%, level IV, V가 5 10\%를 차지한다. ${ }^{1-3)}$ 경부 악성 종양 중 약 80\%는 전이된 경부림프절이며 level I, II, III에 위 치하는 경우 두경부 영역의 원발암에서 주로 유래한다. ${ }^{1-3)}$

경부 전이암의 치료는 원발 부위의 위치에 따라 다르기 때 문에 원발 부위를 찾는 것이 중요한데, 원발 부위에 대한 검사 로는 신체검사, 두경부 내시경검사, 전산화단층화촬영(CT), 자기공명영상(MRI), 양전자단층촬영(PET/CT), 유도 생검 (guided biopsy) 등이 시행된다. 기본 검사로 신체검사 및 내 시경검사가 이루어지며, 비강, 구강, 비인두, 구인두, 하인두, 후두를 면밀히 관찰한다. 영상검사로 CT, MRI 및 $\mathrm{PET} / \mathrm{CT}$ 등을 실시하여 원발 부위 및 전신 전이에 대한 평가를 할 수 있다. 이러한 검사들에서도 원발 부위를 찾지 못하였을 때는, 유도 생검을 시행하며 편도, 설 기저부, 비인두, 하인두에서 조 직검사를 시행한다. 대부분 원발 부위를 발견할 수 있지만 일련의 검사에서도 원발 부위를 발견하지 못하는 경우를 원발 부위 미상 경부 전이암(metastatic carcinoma of unknown origin, MUO)이라 하며 경부 전이성 암종의 약 3 5\%를 차지 한다. ${ }^{4-7)}$

본 연구에서는 경부 종물을 주소로 내원한 전이성 경부 암 종 환자에서 원발 부위를 찾기 위한 진단방법들의 정확도와 유용성에 대하여 분석하고자 하였다.

\section{대상 및 방법}

1998년 1월부터 2016년 6월까지 한양대학교병원 이비인후 과에 경부 종물을 주소로 내원한 환자 중 세침 흡인 세포검 사를 통해 전이성 암종(metastatic carcinoma)으로 확인된 환자를 대상으로 의무 기록을 후향적으로 분석하였다(GURI 2017-10-034). 세침 흡인 세포검사상 전이성 갑상선암, 림프 종(lymphoma)으로 확인되거나 원발 부위가 두경부 영역 외 로 밝혀진 경우는 제외하였다. 총 66명이 본 연구에 포함되었 으며, 대상 환자의 세포학적 및 병리학적 소견, 임상적 특성, 전이성 경부 종물의 위치 및 크기, 원발 부위의 위치 등에 대 하여 분석하였다. 원발 부위를 찾기 위한 진단방법으로는 신 체검사, 두경부 내시경검사, 영상검사(CT, MRI, PET/CT), 그리고 유도 생검이 시행되었으며, 각 검사법별로 원발 부위 를 찾을 확률, 확인된 원발 부위의 분포 및 각 검사의 민감도 (sensitivity), 특이도(specificity), 양성 예측도(positive predictive value), 음성 예측도(negative predictive value)와 정확도 (accuracy)를 분석하였다. 유도 생검은 전신마취하에 편도,
비인두, 설 기저부, 하인두(piryform sinus)에서 시행되었다. 위 내시경검사와 기관지 내시경검사는 필요시 시행하였으며 모든 환자에서 시행하지는 않았다.

\section{결 과}

총 66명의 평균 나이는 58.7세(23 88세), 성별은 남성이 55 명(83.3\%)으로 여성(11명)에 비해 5배 많았다. 처음 내원 시 확인된 전이성 경부 종물의 위치는 level II가 66명 중 60명 (90.9\%)으로 가장 많았고, 차례로 level III가 34명(51.5\%), level IV가 20명(30.3\%), level I이 5명(7.6\%), level V가 4명 (6.1\%)이었다. 경부 종물의 크기는 평균 $3.44 \pm 0.72 \mathrm{~cm}(2.1$ 6.5)였으며, $3 \mathrm{~cm}$ 초과 $6 \mathrm{~cm}$ 이하인 경우가 53명(80.6\%)으로 가장 많았으며 영상학적으로 전이가 의심되는 경부 종물이 있 는 레벨(level I V) 수는 평균 2.1 \pm 0.8 개(1 5)였다. 세침 흡인 세포검사상 편평세포암종(squamous cell carcinoma)이 55명 (83.3\%)으로 가장 많았으며, 비인두암 중 각화형(nasopharyngeal carcinoma, keratinizing type)이 2명(3.0\%), 비각화형(nasopharyngeal carcinoma, non-keratinizing type)이 1명(1.5\%), 미분화형(nasopharyngeal carcinoma, undifferentiated)이 6 명(9.1\%)이었으며, 선암(adenocarcinoma)은 2명(3.0\%)이었 다. 치료는 47명(71.2\%)에서 경부 절제술을 시행하였고, 그중 술 후 방사선 치료를 받은 환자가 27명(40.9\%), 방사선, 항암 동시 치료를 받은 환자가 17명(25.8\%)이었으며, 단독으로 경 부 절제술만 받은 환자는 3명(4.5\%)이었다. 단일 방사선 치료 만 받은 환자는 2 명(3.0\%), 항암 치료만 받은 환자는 1 명 (1.5\%), 방사선, 항암 동시 치료를 받은 환자는 10명(15.2\%)이 었다(Table 1).

원발 부위의 위치는 편도가 30예(45.5\%)로 가장 많았으며, 비인두 11명(16.7\%), 설 기저부 6명(9.1\%), 하인두 6명(9.1\%) 순 이었다. 그 외 구강저부 2 명, 연구개, 설하선, 경부 식도 각 1 명 (1.5\%)이었다. 신체검사, 두경부 내시경검사, CT, MRI, PET/ $\mathrm{CT}$ 및 유도 생검에서도 원발 부위가 확인되지 않아 최종적 으로 원발 부위 미상 경부 전이암(MUO)으로 밝혀진 경우 는 8 명(12.1\%)이었다. 최종 병리학적 결과는 편평세포암종이 54 명(81.8\%)으로 가장 많았다. 이어서 비인두 각화암, 비각화 암이 각 2명(3.0\%), 미분화암이 7명(10.6\%), 선암(adenocarcinoma)이 1 명 $(1.5 \%)$ 이었다. 원발 부위 미상 경부 전이암 8 예 는 세포학적으로 편평세포암종이 7명(87.5\%), 미분화형 암종 이 1명(12.5\%)이었다. T 병기는 T2가 32명(48.5\%), T1이 16명 (24.2\%) 순이었고 N 병기는 N2a, N2b, N2c가 차례로 26명 (39.4\%), 23명(34.8\%), 8명(12.1\%) 순이었다. 원발 부위별로도 모두 처음 전이가 있었던 종물의 위치는 level II, III가 가장 
많았으며 T 병기는 T2가 가장 많았고 N 병기는 N2a, N2b가 많은 분포를 보였다(Table 2).

세포학적 검사가 최종 병리결과와 일치하지 않았던 경우 는 3예로 그중 2예는 비인두가 원발 부위였으며 경부 림프절 세포검사에서 편평세포암종으로 보고되었다가 최종 병리학 적 검사상 비인두암 비각화형과 미분화형으로 밝혀졌다. 편 도에서 1예가 선암종으로 보고되었다가 편평세포암종으로 확인되었다.

신체검사 및 두경부 내시경검사는 모든 례에서 시행되었으 며 36예(54.5\%)에서 원발 부위를 찾을 수 있었다. CT도 모든 례에서 시행되었으며 41예(62.1\%)에서 원발 부위를 찾을 수 있 었다. MRI는 52예에서 시행되었고 이 중 39예(75.0\%)에서 원발 부위를 찾을 수 있었다. PET/CT는 63예에서 시행하였 으며 46예(73.1\%)에서 원발 부위를 찾을 수 있었다(Table 3).

신체검사와 두경부 내시경검사로 원발 부위를 찾지 못했 던 30예 중 CT 또는 MRI의 영상학적 검사를 통해 원발 부

Table 1. Initial clinical and cytological manifestations in patients with metastatic neck mass

\begin{tabular}{|c|c|}
\hline Variable & Total patients $(n=66)$ \\
\hline Age (year) & $58.7 \pm 12.6(23-88)$ \\
\hline Sex (male/female) & $55 / 11$ \\
\hline Metastatic LN site (I/II/III/IV/V) & $5 / 60 / 34 / 20 / 4$ \\
\hline \multicolumn{2}{|l|}{ LN size (largest, \%) } \\
\hline$\leq 3 \mathrm{~cm}$ & $9(13.6)$ \\
\hline$>3 \mathrm{~cm}$ and $\leq 6 \mathrm{~cm}$ & $53(80.6)$ \\
\hline$>6 \mathrm{~cm}$ & $4(6.1)$ \\
\hline Number* of level of metastatic LN & $2.1 \pm 0.8(1-5)$ \\
\hline \multicolumn{2}{|l|}{ Cytology result (\%) } \\
\hline Squamous cell carcinoma & $55(83.3)$ \\
\hline $\begin{array}{l}\text { Nasopharyngeal carcinoma, } \\
\text { keratinizing }\end{array}$ & $2(3.0)$ \\
\hline $\begin{array}{l}\text { Nasopharyngeal carcinoma, } \\
\text { non-keratinizing }\end{array}$ & $1(1.5)$ \\
\hline $\begin{array}{l}\text { Nasopharyngeal carcinoma, } \\
\text { undifferentiated }\end{array}$ & $6(9.1)$ \\
\hline Adenocarcinoma & $2(3.0)$ \\
\hline \multicolumn{2}{|l|}{ Treatment modality (\%) } \\
\hline Neck dissection, only & $3(4.5)$ \\
\hline $\begin{array}{l}\text { Neck dissection with radiation } \\
\text { therapy }\end{array}$ & $27(40.9)$ \\
\hline $\begin{array}{l}\text { Neck dissection with } \\
\text { chemoradiation therapy }\end{array}$ & $17(25.8)$ \\
\hline Radiation therapy, only & $2(3.0)$ \\
\hline Chemotherapy, only & $1(1.5)$ \\
\hline Concurrent chemoradiation therapy & $10(15.2)$ \\
\hline No treatment ${ }^{\dagger}$ & $6(9.1)$ \\
\hline Follow up period (month) & $44.2 \pm 39.7(1-151)$ \\
\hline
\end{tabular}

*the number of metastatic LN level by radiologic finding, tfollow up loss or transfer. LN: lymph node
위를 확인한 경우는 10 예(33.3\%)였으며 편도 6예, 비인두 2 예, 구강저부 1예, 설하선 1예였다. 신체검사 및 내시경검사, $\mathrm{CT}, \mathrm{MRI}$ 에서도 원발 부위가 확인되지 않은 20예 중 PET/ $\mathrm{CT}$ 를 통해 원발 부위가 새로이 확인된 경우는 9예(45.0\%)였 고 편도 7예, 설 기저부 1예, 경부 식도 1예였다. 유도 생검은 이상의 모든 검사에서도 원발 부위를 찾을 수 없었던 11예에 서 시행되었고 그중 3예(27.3\%)에서 원발 부위를 확인할 수 있었으며, 편도 2예, 설 기저부 1예였다.

신체검사 및 내시경검사에서 원발 부위를 찾았던 36예를 제외한 30예 중 CT, MRI 및 PET/CT를 모두 시행한 환자

Table 2. Distribution of primary site and pathologic results in patients with metastatic neck mass

\begin{tabular}{|c|c|}
\hline Variable & $\begin{array}{c}\text { Total } \\
\text { patients }(n=66)\end{array}$ \\
\hline \multicolumn{2}{|l|}{ Primary site } \\
\hline Tonsil & $30(45.5 \%)$ \\
\hline Initial metastatic LN site(I/II/III/IV/V) & $2 / 28 / 15 / 8 / 3$ \\
\hline Initial metastatic LN number* & $2.3 \pm 1.0(1-5)$ \\
\hline T classification (Tx/Tis/T1/T2/T3/T4a/T4b) & $0 / 0 / 10 / 17 / 2 / 1 / 0$ \\
\hline N classification (N1/N2a/N2b/N2c/N3) & $2 / 9 / 16 / 2 / 1$ \\
\hline Base of tongue & $6(9.1 \%)$ \\
\hline Initial metastatic LN site(I/II/III/IV/V) & $0 / 6 / 5 / 2 / 0$ \\
\hline Initial metastatic LN number* & $1.8 \pm 0.8(1-3)$ \\
\hline T classification (Tx/Tis/T1/T2/T3/T4a/T4b) & $0 / 0 / 2 / 1 / 0 / 3 / 0$ \\
\hline $\mathrm{N}$ classification (N1/N2a/N2b/N2c/N3) & $2 / 1 / 1 / 1 / 1$ \\
\hline Nasopharynx & $11(16.7 \%)$ \\
\hline Initial metastatic LN site(I/II/III/IV/V) & $1 / 11 / 4 / 4 / 0$ \\
\hline Initial metastatic LN number* & $2.6 \pm 0.8(1-3)$ \\
\hline T classification (Tx/Tis/T1/T2/T3/T4a/T4b) & $0 / 0 / 2 / 8 / 1 / 0 / 0$ \\
\hline $\mathrm{N}$ classification (N1/N2a/N2b/N2c/N3) & $1 / 7 / 3 / 0 / 0$ \\
\hline Hypopharynx & $6(9.1 \%)$ \\
\hline Initial metastatic LN site(I/II/III/IV/V) & $1 / 5 / 5 / 3 / 1$ \\
\hline Initial metastatic LN number* & $2.3 \pm 0.5(2-3)$ \\
\hline T classification (Tx/Tis/T1/T2/T3/T4a/T4b) & $0 / 0 / 2 / 2 / 1 / 1 / 0$ \\
\hline $\mathrm{N}$ classification (N1/N2a/N2b/N2c/N3) & $0 / 3 / 1 / 2 / 0$ \\
\hline Others $^{\dagger}$ & $5(7.6 \%)$ \\
\hline MUO & $8(12.1 \%)$ \\
\hline \multicolumn{2}{|l|}{ Final pathology result } \\
\hline Squamous cell carcinoma & $54(81.8 \%)$ \\
\hline Nasopharyngeal carcinoma, keratinizing & $2(3.0 \%)$ \\
\hline $\begin{array}{l}\text { Nasopharyngeal carcinoma, } \\
\text { non-keratinizing }\end{array}$ & $2(3.0 \%)$ \\
\hline $\begin{array}{l}\text { Nasopharyngeal carcinoma, } \\
\text { undifferentiated }\end{array}$ & $7(10.6 \%)$ \\
\hline Adenocarcinoma & $1(1.5 \%)$ \\
\hline T classification (Tx/Tis/T1/T2/T3/T4a/T4b) & $8 / 0 / 16 / 32 / 4 / 6 / 0$ \\
\hline N classification (N1/N2a/N2b/N2c/N3) & $5 / 26 / 23 / 8 / 4$ \\
\hline
\end{tabular}

*the number of metastatic LN level by radiologic finding, tfloor of mouth, soft palate, sublingual gland, cervical esophagus. LN: lymph node, MUO: metastatic carcinoma of unknown origin 
21 명을 대상으로 각 검사의 정확도를 분석하였다. 진음성 (true negative)은 유도 생검까지의 모든 검사에서도 원발 부 위를 찾지 못하여 최종적으로 원발 부위 미상 경부 전이암으 로 밝혀진 경우(8명)로 정의하였다. 위양성은 존재하지 않아 특이도와 양성 예측도는 모두 $100 \%$ 로 동일하였으며 검사별 민감도, 음성 예측도, 정확도는 차이가 있었다. CT는 23.1, 44.4, 52.4\%, MRI는 61.5, 61.5, 72.2\%, PET/CT는 84.6, 80.0, $90.5 \%$ 에 해당하였다(Table 4).

원발 부위별 분석에서 편도는 30예 중 신체검사 및 내시경 검사로 15예(50\%), CT 17예(57\%), MRI 19예(63\%), PET/CT 25예(83\%)에서 원발 부위가 확인되었다. 설 기저부는 6예 중 신체검사 및 내시경검사에서 4예(67\%)에서 확인되었으며 CT 와 MRI에서 추가로 확인된 경우는 없었으나, PET/CT에서 추가로 1 예가 발견되어 총 5 예(83\%)에서 원발 부위가 확인되 었다. 비인두는 11예 중 신체검사 및 내시경검사로 9예(82\%), CT로 11예(100\%), MRI로 7예(64\%), PET/CT로 7예(64\%)에 서 원발 부위가 확인되었으며, 하인두는 6예 모두 내시경검 사에서 확인할 수 있었고 영상의학적 검사에서도 모두 원발 부위가 확인되었다(Fig. 1).

각 원발 부위에서 검사 단계에 따른 분석에 있어, 편도는 신체검사 및 내시경검사만으로 15 명(50\%)이 확인되었고, CT 에서 2명, MRI에서 4명, PET/CT에서 7명, 유도 생검에서 2명 이 추가로 확인되었다. 설 기저부는 신체검사 및 내시경검사 에서 4명 $67 \%)$, PET/CT에서 1명, 유도 생검에서 1명이 추가 로 확인되었다. 비인두에서는 신체검사 및 내시경검사에서 9 명(82\%), CT에서 추가로 2명이 확인되었으며, 하인두는 신체 검사 및 내시경검사만으로 6명(100\%)이 모두 확인되었다 (Fig. 2).

Table 3. Detection of primary site according to diagnostic modality

\begin{tabular}{lc}
\hline \multicolumn{1}{c}{ Diagnostic method } & Number of patients (\%) \\
\hline $\begin{array}{l}\text { Physical examination, } \\
\text { laryngofiberscopy }\end{array}$ & $36 / 66(54.5)$ \\
CT & $41 / 66(62.1)$ \\
MRI & $39 / 52(75.0)$ \\
PET/CT & $46 / 63(73.1)$ \\
Guided biopsy & $3 / 11(27.3)$ \\
\hline
\end{tabular}

원발 부위 미상 경부 전이암으로 진단된 8예는 수술 및 방사 선 치료 이후 $23.9 \pm 22.3$ 개월의 추적관찰 기간 동안 원발 부위 가 새로이 발견된 례는 없었다.

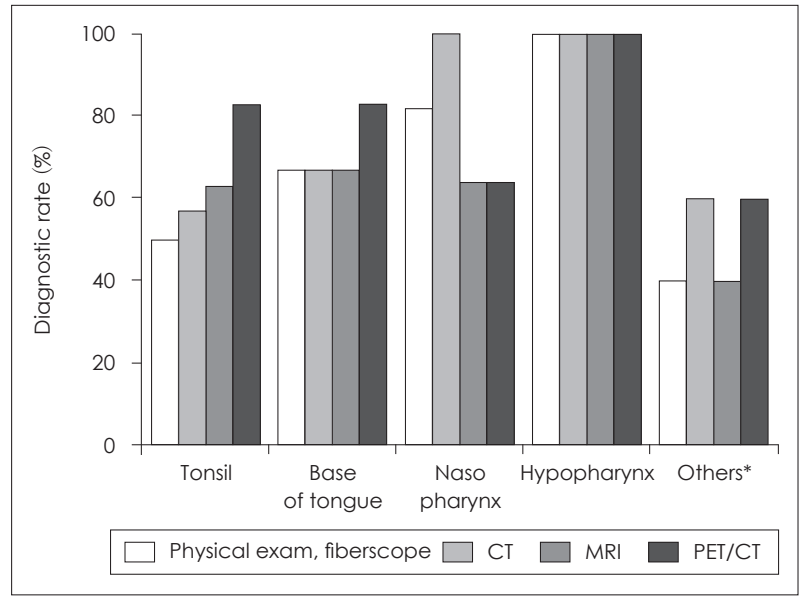

Fig. 1. Identification rate of diagnostic modality according to primary site. *floor of mouth, soft palate, sublingual gland, cervical esophagus.

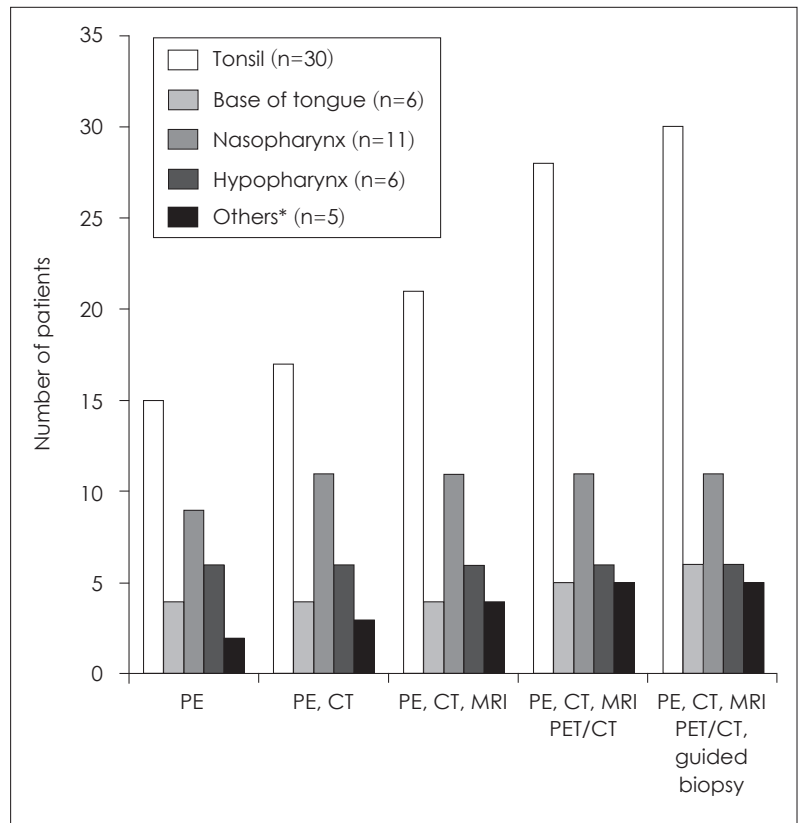

Fig. 2. Detection of primary site according to each diagnostic step. *floor of mouth, soft palate, sublingual gland, cervical esophagus. PE: physical and endoscopic exam.

Table 4. Accuracy of radiologic modalities in patients with metastatic neck mass

\begin{tabular}{lccccc}
\hline \multicolumn{5}{c}{ Validity* of included patients $(\mathrm{n}=21)$} \\
\hline Diagnostic method & Sensitivity (\%) & Specificity (\%) & Positive predictive value (\%) & Negative predictive value (\%) & Accuracy (\%) \\
\hline CT & 23.1 & 100 & 100 & 44.4 & 52.4 \\
MRI & 61.5 & 100 & 100 & 61.5 & 72.2 \\
PET/CT & 84.6 & 100 & 100 & 80.0 & 90.5 \\
\hline
\end{tabular}

*true negative means true metastatic carcinoma of unknown origin. There was no false positive in this study 


\section{고 찰}

전이성 경부 종물은 40대 이상에서 호발하고 남자가 여자에 비해 2배에서 5.6배까지 많다.,2) 본 연구에서도 연령 평균 58.7세였고 남자가 여자에 비해 5 배 많았다. 경부 전이암에서 가장 큰 전이성 림프절 크기의 평균값은 $5 \sim 6 \mathrm{~cm}$, 병기는 N2 가 가장 많으며 전이 위치는 다소 차이는 있으나 level II가 가장 흔히 침범되고 이어 level I, III가 비슷한 분포를 보인 다. ${ }^{2-48}$ 본 연구에서도 전이성 경부 종물의 크기는 $3 \mathrm{~cm}$ 초과 $6 \mathrm{~cm}$ 이하인 경우가 대부분이었으며 N2 병기가 가장 많았고 위치는 level II를 포함한 경우가 $90.9 \%$ 로 가장 많은 빈도를 보였다.

병리학적 분포는 편평세포암종이 가장 흔하고 뒤이어 미분 화 암종, 선암종의 순으로 알려져 있다. ${ }^{2,3)}$ 원발 부위의 분포 는 구인두(편도 및 설 기저부)가 가장 많고 하인두 또는 비인 두가 그 다음 순서로 보고된다. ${ }^{9-12)}$ 본 연구에서도 병리결과 상 편평세포암종이 전체의 $84.8 \%$ 로 가장 많은 빈도를 보였고 다음으로 미분화 암종이 $10.6 \%$ 의 분포를 보였다. 확인된 원발 부위는 편도가 30예(45.5\%)로 가장 많았고 비인두 11예(16.7\%), 설 기저부 6예(9.1\%), 하인두 6예(9.1\%)였다.

신체검사와 내시경검사는 가장 먼저 시행하는 기본 검사이 며, 경부 전이성 편평세포암종 환자의 원발 부위 진단에서 신 체검사만으로 43 53\%에서 원발 부위를 찾을 수 있다고 보 고된다. ${ }^{10,11)}$ 본 연구에서도 전이성 경부 종물 환자에서 신체 검사와 두경부 내시경검사를 통해 $54.5 \%(36 / 66)$ 에서 원발 부 위를 찾을 수 있었다.

본 연구에서 각각의 원발 부위에 따라 분석하면, 비인두 및 하인두는 신체검사 및 내시경검사를 통해 각 $83 \%, 100 \%$ 에 서 원발 부위를 찾을 수 있는 반면, 편도와 설 기저부의 경우 각 $50,67 \%$ 에서 원발 부위를 확인할 수 있었다. 편도와 설 기 저부에서 신체검사와 내시경검사로 원발 부위의 확인이 어려 운 이유는 병변의 위치가 편도 소와(tonsillar crypt) 등 육안 으로 관찰하기 어려운 곳에 위치하는 경우가 빈번하며 주위 에 림프 조직이 많아 크기가 작은 병소는 신체검사와 내시경, 방사선 검사로 발견하기가 어렵기 때문이다.,13)

본 연구에서 신체검사 및 두경부 내시경검사와 $\mathrm{CT}, \mathrm{MRI}$ 의 영상의학적 검사에도 원발 부위를 찾을 수 없었던 경우 는 20예(30.3\%)였으며 이전의 다른 연구들에서도 영상의학 적 검사까지 시행하였을 때 원발 부위를 확인할 수 없었던 경 우가 20.0 53.4\%로 보고된다. ${ }^{50-12)}$ 본 연구에서도 신체검사와 $\mathrm{CT}, \mathrm{MRI}$ 에서 원발 부위가 확인되지 않은 20예 중 PET/CT 를 통해 9예에서 원발 부위가 추가로 확인되었으며 그중 7예 가 편도, 2예가 설 기저부였다. PET/CT는 기존의 CT와 MRI
의 해부학적 정보에, 종양 자체에서 섭취되는 fluoro-deoxyglucose 대사를 통해 생리학적 정보를 추가로 얻을 수 있어 기존의 영상학적 검사보다 원발 부위 진단에 장점이 있다. ${ }^{14)}$ 원발 부위 미상 경부 전이암의 진단에 관한 이전의 연구들에 서 기존 영상의학적 검사에 $\mathrm{PET} / \mathrm{CT}$ 를 시행함으로써 원발 부위 진단이 약 15 44\%까지 향상되었다고 보고된다..$^{14-19)}$ 원 발 부위 미상 경부 전이암의 원발 부위 진단에 있어 PET/CT 의 역할에 대한 메타 분석연구에서 $\mathrm{PET} / \mathrm{CT}$ 자체의 진단율 은 $37 \%$, 민감도 $84 \%$, 특이도 $84 \%$ 로 보고되었다. ${ }^{19)}$ Roh 등 ${ }^{16)}$ 은 원발 부위 미상 경부 전이암에서 원발 부위를 찾기 위한 검사로 $\mathrm{PET} / \mathrm{CT}$ 는 $94 \%$ 의 민감도로 CT의 $71.6 \%$ 보다 $22.4 \%$ 가 높으며 특이도는 각 $94.8,96.5 \%$ 로 비슷하다고 보고한 바 있다. 본 연구에서도 PET/CT의 민감도는 $84.6 \%$ 로 CT(23.1\%), MRI(61.5\%)에 비해서 우수한 결과를 보였으며, 정확도 역시 $90.5 \%$ 로 CT(52.4\%), MRI(72.2\%)보다 높았다. 특히, 편도와 설 기저부는 경부 전이암에서 가장 많은 빈도를 차지하는 원 발 부위로, 다른 부위에 비해 진찰실에서의 신체검사와 $\mathrm{CT}$, $\mathrm{MRI}$ 검사로 진단하기가 어려워 $\mathrm{PET} / \mathrm{CT}$ 가 유용한 진단적 도 구가 될 수 있다.

신체검사, 두경부 내시경검사, 및 영상학적 검사에서도 원 발 부위를 찾지 못하였을 때, 편도, 설 기저부, 하인두, 비인두 등에서 유도 생검을 선별적으로 시행하게 된다. 본 연구에서도 유도 생검은 영상의학적 검사와 PET/CT에서도 원발 부위를 찾을 수 없었던 11예에서 시행되었는데, 편도 2예, 설 기저부 1 예, 총 3 예 $(3 / 11,27.3 \%)$ 에서 원발 부위를 확인할 수 있었다. 다 른 연구들도 영상검사로 원발 부위가 확인되지 않는 경우 유 도 생검을 시행하였고 시행한 환자의 $16 ~ 25 \%$ 에서 원발 부위 를 찾을 수 있었다고 보고하였다. ${ }^{10-12}$

유도 생검에서 발견되는 전이성 경부 종물의 원발 부위는 내 시경검사가 미흡했던 과거에는 비인두가 가장 많았으나 최근 에는 내시경검사 장비의 발전으로 오히려 편도, 설 기저부에 서 더 많이 보고된다. ${ }^{1,2,11)}$ 또한 $\mathrm{PET} / \mathrm{CT}$ 의 발전으로 $\mathrm{CT}$ 나 MRI에서는 발견되지 않던 크기가 작은 구인두 종양의 진단 이 용이해져 과거에 비해 편도 및 설 기저부에서 악성종양이 많이 발견된다. ${ }^{16}$ 편도와 설 기저부는 그 위치, 삼킴에 의한 움 직임, 주위에 많이 분포하는 림프조직, 지방조직, 침 등에 의 해 육안이나 영상의학적 검사로도 진단이 어렵다. ${ }^{9,13)}$ 이러한 이유로 편도와 설 기저부에서의 보다 정확한 조직병리적 확 인이 필요하다고 주장하는 연구들이 있다.11,13,20) 이에 대한 한 연구에서는 전이성 경부암종 중 편평세포암종 환자에 대한 연구에서 통상의 검사에서 원발 부위를 발견하지 못하였을 때, 설편도 절제술(lingual tonsillectomy)을 통해 67 72\%에 서 추가로 원발 부위 진단을 할 수 있었다고 보고된 바 있 
다. ${ }^{13)}$ 편도 또한 조직검사가 추천되는 원발 부위이며, 그 방법 으로는 편도 심부 조직검사(deep tonsil biopsy)보다 편도 절 제술(tonsillectomy)에서 약 $26 \%$ 우수한 진단율을 보인다고 보고된 바 있다. ${ }^{20)}$

본 연구는 대상 환자군이 적고, 후향적 연구라는 필연적 단 점이 있으며, 모든 환자에서 동일한 검사를 시행하지 않아 검 사법의 정확성을 직접 비교할 수 없다는 한계점이 있다. 그러 나 경부 전이암의 임상적 양상 및 원발 부위 진단검사에 있어 $\mathrm{PET} / \mathrm{CT}$ 의 유용성과 유도 생검의 필요성을 확인할 수 있었다.

결론적으로 본 연구에서 경부 전이암의 원발 부위는 편도, 비인두, 설 기저부, 하인두 순의 빈도를 보였으며, 신체검사와 두경부 내시경검사로 $55 \%$ 에서 원발 부위를 찾을 수 있었다. 신체검사, 내시경검사 및 $\mathrm{CT} / \mathrm{MRI}$ 에서 원발 부위가 발견되지 않은 경우, PET/CT와 유도 생검은 추가로 원발 부위를 진단 할 수 있는 유용한 검사라 사료된다.

\section{REFERENCES}

1) Oh KK, Lee GH, Lee YS, Shim YS. Neck masses: a clinical analysis. Korean J Otolaryngol-Head Neck Surg 1992;35(5):650-6.

2) Wang SG. Differential diagnosis and treatment of neck masses. J Korean Med Assoc 2007;50(7):613-25.

3) Müller von der Grün J, Tahtali A, Ghanaati S, Rödel C, Balermpas P. Diagnostic and treatment modalities for patients with cervical lymph node metastases of unknown primary site-current status and challenges. Radiat Oncol 2017;12(1):82.

4) Talmi YP, Wolf GT, Hazuka M, Krause CJ. Unknown primary of the head and neck. J Laryngol Otol 1996;110(4):353-6.

5) Greco FA, Hainsworth JD. Cancer of unknown primary site. In: DeVita VT Jr, Hellman S, Rosenberg SA, editors. Cancer: Principles and Practice of Oncology. 7th ed. Philadelphia: Lippincott Williams \& Wilkins;2005. p.2213-36.

6) Strojan P, Ferlito A, Medina JE, Woolgar JA, Rinaldo A, Robbins KT, et al. Contemporary management of lymph node metastases from an unknown primary to the neck: I. a review of diagnostic approaches. Head Neck 2013;35(1):123-32.

7) Waltonen JD, Ozer E, Hall NC, Schuller DE, Agrawal A. Metastatic carcinoma of the neck of unknown primary origin: evolution and efficacy of the modern workup. Arch Otolaryngol Head Neck Surg 2009;135(10):1024-9.

8) Grau C, Johansen LV, Jakobsen J, Geertsen P, Andersen E, Jensen BB.
Cervical lymph node metastases from unknown primary tumours. Results from a national survey by the Danish Society for Head and Neck Oncology. Radiother Oncol 2000;55(2):121-9.

9) Švajdler M Jr, Kašpírková J, Hadravský L, Laco J, Dubinský P, Straka $\mathrm{L}$, et al. Origin of cystic squamous cell carcinoma metastases in head and neck lymph nodes: addition of EBV testing improves diagnostic accuracy. Pathol Res Pract 2016;212(6):524-31.

10) Jones AS, Cook JA, Phillips DE, Roland NR. Squamous carcinoma presenting as an enlarged cervical lymph node. Cancer 1993;72(5): 1756-61.

11) Ahn Y, Han DH, Hah JH, Kwon TK, Sung MW, Kim KH. Analysis on diagnostic approach, management and prognosis of cervical metastatic carcinoma of unknown origin. Korean J OtorhinolaryngolHead Neck Surg 2007;50(12):1125-9.

12) Mendenhall WM, Mancuso AA, Parsons JT, Stringer SP, Cassisi NJ. Diagnostic evaluation of squamous cell carcinoma metastatic to cervical lymph nodes from an unknown head and neck primary site. Head Neck 1998;20(8):739-44.

13) Fu TS, Foreman A, Goldstein DP, de Almeida JR. The role of transoral robotic surgery, transoral laser microsurgery, and lingual tonsillectomy in the identification of head and neck squamous cell carcinoma of unknown primary origin: a systematic review. J Otolaryngol Head Neck Surg 2016;45(1):28.

14) Pelosi E, Pennone M, Deandreis D, Douroukas A, Mancini M, Bisi G. Role of whole body positron emission tomography/computed tomography scan with $18 \mathrm{~F}$-fluorodeoxyglucose in patients with biopsy proven tumor metastases from unknown primary site. Q J Nucl Med Mol Imaging 2006;50(1):15-22.

15) Al-Ibraheem A, Buck A, Krause BJ, Scheidhauer K, Schwaiger M. Clinical applications of FDG PET and PET/CT in head and neck cancer. J Oncol 2009;2009:208725.

16) Roh JL, Kim JS, Lee JH, Cho KJ, Choi SH, Nam SY, et al. Utility of combined (18)F-fluorodeoxyglucose-positron emission tomography and computed tomography in patients with cervical metastases from unknown primary tumors. Oral Oncol 2009;45(3):218-24.

17) Keller F, Psychogios G, Linke R, Lell M, Kuwert T, Iro H, et al. Carcinoma of unknown primary in the head and neck: comparison between positron emission tomography (PET) and PET/CT. Head Neck 2011;33(11):1569-75.

18) Rusthoven KE, Koshy M, Paulino AC. The role of fluorodeoxyglucose positron emission tomography in cervical lymph node metastases from an unknown primary tumor. Cancer 2004:101(11):2641-9.

19) Kwee TC, Kwee RM. Combined FDG-PET/CT for the detection of unknown primary tumors: systematic review and meta-analysis. Eur Radiol 2009;19(3):731-44.

20) Waltonen JD, Ozer E, Schuller DE, Agrawal A. Tonsillectomy vs. deep tonsil biopsies in detecting occult tonsil tumors. Laryngoscope 2009;119(1):102-6. 